\title{
Variations in Fertility Levels in Bovines
}

\section{By J. Edwards, The Milk Marketing Board, Thames Ditton, Surrey}

The relatively new movement of artificial insemination (A.I.) is producing a mass of documented breeding information for bovines which is unique. In England and Wales there are this year more than 40,000 herds of cows that are being inseminated and for which individual cow and herd conception-rates are kept. In addition, semen collections are being taken, on the average weekly, from about $45^{\circ}$ bulls whose fertility rates are known. We have here an extremely good background to studies on fertility and, although this paper throws little direct light on nutritional influences already observed, it will attempt to described the position as seen by the 'field observer' and to mention some of the problems of defining standards of fertility.

\section{Cows}

It may be permissible first to emphasize how important fertility is to the dairying industry. The country's milk supply depends on cows being got in calf, and milk for the winter depends on this being done at the right time. How difficult this is is known to the farmer who, although he would like to calve most of his cows in October, finds that their breeding cycles tend to get out of control and so force him to rely on his heifer replacements. This is shown in Table $\mathbf{I}$ quoting October calvings (as a percentage of the annual) for cows and heifers in recorded herds in eleven English and Welsh counties.

Table 1. Percentage calvings in October $($ year $=100)$ for cows and heifers in recorded herds in eleven English and Welsh counties

\begin{tabular}{lcc}
\multicolumn{1}{c}{ County } & Cows & Heifers \\
Cumberland & 13.2 & 20.3 \\
Lancashire & 14.1 & 16.4 \\
Norfolk & 16.6 & 26.3 \\
Northamptonshire & 15.5 & $20 \cdot 7$ \\
Shropshire & 14.3 & 19.3 \\
Anglesey and Caernarvon & 12.6 & 20.1 \\
Cardiganshire & 10.4 & $11 \cdot 8$ \\
Hampshire & 12.7 & 21.5 \\
Wiltshire & $15 \cdot 8$ & 29.6 \\
Cornwall & 13.0 & 19.9 \\
Essex & 12.0 & 19.1 \\
All counties & 13.9 & $21 \cdot 5$
\end{tabular}

The amount of variation among cows is very much less than among heifers, and the extent to which the heavy winter-milk producing counties rely on the latter (e.g. Wiltshire, $29.6 \%$ and Norfolk, $26.3 \%$ ) is obvious. These heifers later become cows and are not again so successfully grouped for winter milk. As heifers they are not in milk when they are first got in calf, but as cows they have to milk and conceive at the same time; is it a nutritional deficiency which impairs breeding efficiency in the latter state?

The A.I. service from a large centre is able to reveal differences in fertility levels 
within herds. Over its operations in 1946 the average conception rate at Board centres was $64.6 \%$ ( 17,000 cows) and in $194764.4 \%(63,500$ cows). (The conception rate (c.R.) is the percentage of cows inseminated for the first time which are assumed to be in calf if they have not returned to service after an interval of 3 months, i.e. the number of 'first takes' per roo inseminations.) This C.R. of $64 \%$ is a good base for a variety of comparisons. For one of them-an examination of fertility levels in herds of ten or more cows-the results are seen in Table 2.

Table 2. Conception rates within herds of ten or more cows

\begin{tabular}{|c|c|c|c|c|}
\hline \multirow{2}{*}{$\begin{array}{c}\text { Initial conception } \\
\text { rate }(\%)\end{array}$} & \multicolumn{2}{|c|}{ I $947^{-8}$ herds } & \multicolumn{2}{|c|}{$194^{6-7}$ herds } \\
\hline & No. & Percentage of total & No. & Percentage of total \\
\hline$<25$ & $2 I$ & $I \cdot 2$ & 5 & $I \cdot I$ \\
\hline $25-49$ & 306 & $16 \cdot 6$ & 88 & 19.7 \\
\hline $50-74$ & I IOI & $59 \cdot 7$ & 259 & $57 \cdot 9$ \\
\hline $75-99$ & 393 & $21 \cdot 3$ & 88 & 19.7 \\
\hline 100 & 22 & $I \cdot 2$ & 7 & $I \cdot 6$ \\
\hline Total & $x 843$ & 100.0 & 447 & $100 \cdot 0$ \\
\hline
\end{tabular}

It will be seen that about eighteen herds in roo have a c.R. of less than $50 \%$ and that twenty to twenty-two herds in I00 range between a C.R. of $75 \%$ to one of $100 \%$. It is common knowledge that contagious diseases in the bovine may have a serious effect on breeding efficiency, but it is the opinion of those who have to deal with A.I. 'trouble herds' that they by no means explain the considerable variations which occur.

A large nutritional difference exists between the winter and summer feeding of the dairy cow. During the former she is fed on concentrated feed, hay, straw, silage and roots; during the latter she is out of doors eating the food nature intended her to have. Do the changes affect her breeding efficiency? The best evidence we have so far is in the results for January-December 1947 and January-September 1948, which, for quarters of the year, are given in Table 3 .

Table 3. Conception rates by season

\begin{tabular}{|c|c|c|c|c|}
\hline \multirow[b]{2}{*}{ Period } & \multicolumn{2}{|c|}{1947} & \multicolumn{2}{|c|}{1948} \\
\hline & $\begin{array}{l}\text { No. of } \\
\text { cows }\end{array}$ & $\begin{array}{l}\text { Conception } \\
\text { rate }(\%)\end{array}$ & $\begin{array}{l}\text { No. of } \\
\text { cows }\end{array}$ & $\begin{array}{l}\text { Conception } \\
\text { rate }(\%)\end{array}$ \\
\hline $\begin{array}{l}\text { January-March } \\
\text { April-June } \\
\text { July-September } \\
\text { October-December }\end{array}$ & $\begin{array}{l}\text { I } 1,644 \\
15,053 \\
10,810 \\
25,988\end{array}$ & $\begin{array}{l}64 \cdot 4 \\
62 \cdot 9 \\
66 \cdot 2 \\
64 \cdot 4\end{array}$ & $\begin{array}{l}37,298 \\
48,698 \\
40,304 \\
*\end{array}$ & $\begin{array}{l}64 \cdot 3 \\
62 \cdot 9 \\
64 \cdot 5 \\
*\end{array}$ \\
\hline Total & 63,495 & $64 \cdot 4$ & 一 & - \\
\hline
\end{tabular}

On the face of it, the differences in C.R. between winter and summer feeding are not great, though there is a slight fall in C.R. in April-June, when the cows go out to grass. The belief is widespread that a farmer's breeding troubles will be over when spring comes and his cows go out to pasture, but our own experience to date suggests that it is optimistic. 
I should like to refer now to a striking drop in C.R. observed at two A.I. centres during the past year. Their quarterly C.R.'s (from January to March 1947 onwards) are shown in Table 4.

Table 4. Quarterly conception rates (\%) at two artificial insemination centres, January $1947^{-S e p t e m b e r} 1948$

\begin{tabular}{|c|c|c|c|c|c|c|c|}
\hline \multirow[b]{2}{*}{ Centre } & \multicolumn{4}{|c|}{ r 947} & \multicolumn{3}{|c|}{1948} \\
\hline & $\begin{array}{l}\text { Jan.- } \\
\text { Mar. }\end{array}$ & $\begin{array}{l}\text { Apr.- } \\
\text { June }\end{array}$ & $\begin{array}{l}\text { July- } \\
\text { Sept. }\end{array}$ & $\begin{array}{l}\text { Oct.- } \\
\text { Dec. }\end{array}$ & $\begin{array}{l}\text { Jan.- } \\
\text { Mar. }\end{array}$ & $\begin{array}{c}\text { Apr.- } \\
\text { June }\end{array}$ & $\begin{array}{l}\text { July- } \\
\text { Sept. }\end{array}$ \\
\hline $\begin{array}{l}\mathrm{A} \\
\mathrm{B}^{*}\end{array}$ & $\begin{array}{l}67 \cdot 8 \\
65 \cdot 1\end{array}$ & $\begin{array}{l}64 \cdot 5 \\
56 \cdot 9\end{array}$ & $\begin{array}{l}65 \cdot 4 \\
63 \cdot 1\end{array}$ & $\begin{array}{l}64 \cdot 5 \\
6 I \cdot I\end{array}$ & $\begin{array}{l}62 \cdot 2 \\
58 \cdot 5\end{array}$ & $\begin{array}{l}49 \cdot 3 \\
48 \cdot 9\end{array}$ & $\begin{array}{l}47 \cdot 8 \\
50 \cdot 6\end{array}$ \\
\hline
\end{tabular}

* This centre calculates its C.R. on a basis that differs slightly from the standard and a reasonable adjustment has been made to bring it into line.

These two centres are situated close to each other, although they are quite separately owned and managed. The drop in C.R. in the April-June quarter (continued into the July-September quarter) is most marked, and the most baffling feature is that at each place the trouble is now disappearing without a cause having been found. A fall in C.R. of this order means a financial embarrassment both to the farmer and the centre.

It is unfortunate that we do not know what was happening in herds in these areas that were using natural service during this difficult period. There were reports of 'waves of infertility' affecting them, but no facts. It is highly desirable to have such controls and the Board's A.r. organization is now obtaining them by a survey of fertility levels in a large number of herds using 'natural service' throughout the country. It is too early to say if any of the results will compare with the phenomenon under discussion, but already there is a picture of a spread of within-herd fertility similar to that shown in Table 2.

I have so far kept to the promise I made at the outset - that the facts presented would throw little direct light on nutritional influences--and I should like to end this section by saying that $I$ feel sure that disease does not explain the variations that occur and that there is a wide field for nutritional investigations.

Bulls

To turn now to the bulls used for A.I.: in the absence of any clear-cut evidence of the effect of feed on sperm production, A.I. bulls are fed a standard concentrate ration (with a supplement of protein of animal origin), dried grass, hay, roots and, in summer, grass and green feed. On this diet individual bulls may differ by as much as 10-15\% in their c.R.'s. ('This is not the limit of variation, for bulls of abnormally low C.R. are withdrawn from service.)

The A.I. movement eagerly awaits the results of research on the effect of nutrition on the volume and density of semen and its fertilizing capacity, and on service activity. I should like to refer only briefly to the question of standards for this kind of work. The semen-producing ability of a bull cannot be judged by one or two test ejaculates, and it is important to realize this, both in experimental work and in testing potential 
A.I. bulls on farms. Table 5 gives the results (Edwards \& Walton, I939) of semen collections from fourteen bulls for $(a)$ ten ejaculates per bull in $2 \mathrm{hr}$. (a semi-exhaustion test) and (b) an average of paired ejaculates (first and second) from the same bulls taken at about fortnightly intervals over a period of $\mathrm{I}$ year.

Table 5. Comparison between sperm produced by fourteen bulls as indicated by (a) an exhaustion test of ten ejaculates and (b) periodic paired tests

\begin{tabular}{|c|c|c|c|}
\hline \multirow[b]{2}{*}{ No. of bull } & \multirow{2}{*}{$\begin{array}{l}\text { Exhaustion test } \\
\text { Total no. of } \\
\text { sperm (millions) }\end{array}$} & \multicolumn{2}{|c|}{$\begin{array}{l}\text { Periodic test } \\
\text { Average total number of sperm } \\
\text { per ejaculate (millions) }\end{array}$} \\
\hline & & First ejaculate & Second ejaculate \\
\hline I & 28,544 & 3108 & 6555 \\
\hline 2 & 20,303 & $2 \times 13$ & 2655 \\
\hline 3 & $18,96 \mathrm{I}$ & 3061 & 3081 \\
\hline 4 & 17,613 & 2905 & 3676 \\
\hline 5 & 16,305 & 2204 & 4711 \\
\hline 6 & 15,959 & 4501 & 4609 \\
\hline 7 & I 5,648 & 4445 & 4948 \\
\hline 8 & $14,87 \mathrm{I}$ & 1896 & 3940 \\
\hline 9 & 13,977 & 2557 & 4772 \\
\hline 10 & I I,79 I & 1163 & 1525 \\
\hline I I & I I, 036 & 4081 & 442 I \\
\hline 12 & 10,280 & 2326 & 2156 \\
\hline 13 & $5,5 \circ 9$ & 1390 & 1067 \\
\hline 14 & 2,879 & I 592 & 1820 \\
\hline
\end{tabular}

It will be seen that neither one nor two test ejaculates reflected the reserves revealed in the exhaustion test. In an experiment with rabbits and by keying the frequency of collection to the rate of spermatogenesis, it has been possible to show (Edwards, I940) that the latter is a direct function of the weight of testicular material: in the rabbit I g. of testes produced 100 million sperm/week. A standard of this kind appears to be desirable.

A most promising future for experimental work on bulls lies in the use of identical twins. MacMeekan (1948) is already satisfied as to the superiority of this kind of material for studies on male fertility and has research in progress on the effects of such factors as the feeding of pasture versus indoor rations, exercise and the effect of different levels of nutrition during the growth period. We need also to know the significance of changes in a bull's own fertility levels throughout the year. There are some who are sceptical of all attempts to influence it-by feeding or hormones-and who, on 2-3 years' experience of routine semen collection from studs of twenty to thirty bulls, are inclined to the view that a good bull is always good and that a doubtful one, because he will always be so, is best disposed of.

\section{REFERENCES}

Edwards, J. (1940). Proc. roy. Soc. B. 128, 407.

Edwards, J. \& Walton, A. (1939). Int. Genetics Congr. vii. Edinburgh, Sect. D, p. 30. MacMeekan, C. P. (1948). Ann. Rep. Ruakura Anim. Res. Sta. N.Z. (Mimeo). 